\title{
Nanoelikagaiak: tamainak axola duenean
}

\author{
Nanofoods: when size does matter
}

Iñigo Lozano, Itziar Galarreta, Sonia Pérez-Yáñez, Idoia Ruiz de Larramendi*

Kimika Ezorganikoa Saila, Zientzia eta Teknologia Fakultatea (UPV/EHU)

LABURPENA: Nanoteknologiaren erabilpena funtsezko erreminta bilakatu da aplikazio askoren garapenean, eta elikagaien sektorea ez da alde batera geratu. Modu horretan, nanoelikagaien garapenak osasuntsuagoak, erresistenteagoak eta iraupen luzeagoa duten elikagaiz gozatzea ahalbidetuko duela uste da. Lan honetan, nanoteknologia elikadura sektorean ezartzeak eragindako aurrerapen nagusiak aurkezten dira eta, bereziki, honako hiru arlo hauetan jarri da arreta: nano-aberastutako elikagaiak, elikagai biltegiratzeko diseinu berriak eta nanosentsoreak. Amaitzeko, elikadura industrian nanoteknologiaren erabilpenak eragindako eztabaida aztertuko da; abantaila asko ekar ditzakeen arren, egun gizartearengan beldurra eta kezkak eragiten baititu.

HITZ GAKOAK: nanoteknologia, elikagaien zientzia, elikagaien paketatze, nanosentsore.

ABSTRACT: The use of nanotechnology has become a key tool for the development of an endless number of applications. The food sector is not an exception since the benefits of nanotechnology are expected to allow us to enjoy healthier, more resilient and long-lasting foods. In this work, we present the main advances related to the introduction of nanotechnology in the food sector, focusing on three areas: nano-enriched foods, novel designs for food packaging and nanosensors. Finally, the controversy surrounding nanofood is analyzed, since although nanotechnology can contribute with lots of benefits, its use still causes fear and insecurity among the population.

KEYWORDS: nanotechnology, food science, food packaging, nanosensor.

\footnotetext{
* Harremanetan jartzeko / Corresponding author: Idoia Ruiz de Larramendi. Kimika Ezorganikoa Saila, Zientzia eta Teknologia Fakultatea, UPV/EHU, Sarriena auzoa, z/g, 48940 Leioa. Bizkaia, Euskal Herria. - idoia.ruizdelarramendi@ehu.eus https://orcid.org/0000-0002-4179-7357.

Nola aipatu / How to cite: Lozano, Iñigo; Galarreta, Itziar; Pérez-Yáñez, Sonia; Ruiz de Larramendi, Idoia (2019). «Nanoelikagaiak: tamainak axola duenean»; Ekaia, 35, 2019, 143-163. (https://doi.org/10.1387/ekaia.19684).

Jasoa: 14 maiatza, 2018; Onartua: 27 azaroa, 2018.

ISSN 0214-9001 - eISSN 2444-3255 / (c) 2019 UPV/EHU
}

(c) (i) () Obra hau Creative Commons Atribución 4.0 Internacional-en

lizentziapean dago 


\section{SARRERA}

Azken 15 urteetan, nanoteknologiaren garapenak izugarrizko iraultza ekarri du ikerkuntza sektore anitzetan, hala nola elektronikan, energian, medikuntzan edo komunikazioen arloan. Elikagaien alorra ez da salbuespena; egun nanoteknologiak sektore horretan duen eragina nabarmena baita.

Nanoteknologiak lan esparru askotan eragina daukanez, zaila da eremu guztiak bateratuko lituzkeen definizio zehatz bat erabiltzea. Europar Batasuneko The Scientific Committee on Emerging and Newly Identified Health Risks (SCENIHR) erakundeak emandako definizioa hartuz gero, nanoteknologia honela defini daiteke: materiaren diseinuak, ekoizpenak, karakterizazioak eta aplikazioak eskala nanometrikoan aurrera eramaten dituen zientzia eta ingeniaritza arloa [1]. Horren harira, material batek nano izendapena izan dezan, gutxienez bere dimentsioetako batek $100 \mathrm{~nm}$-tik behera egon behar du.

Richard P. Feynmanek, 1959an emandako hitzaldian, eskala nanometrikoak izan zezakeen oparotasuna azaleratu zuen arte, nanoteknologia existitzen ez zen adar zientifiko bat zela dirudi [2]. Halere, ikusezina eta detektaezina zen arren, gizakiak antzinatik erabili izan ditu material horiek eskaintzen dituzten propietate paregabeak. Horren eredu dira Bonampakeko (Chiapas, Mexiko) mural aurrehispaniarrak , maia kulturakoak. Mural horiek kolore urdin ikusgarria dute, baso tropikalean 1.000 urteren ostean kontserbatu dena. Burdin oxidozko nanopartikulen (1-10 nm-koak) presentziak eragina du pigmentu horren propietate optikoengan eta egonkortasunarengan [3]. Beste adibide bat beira industrian aurki dezakegu, erromatarren garaitik erabilia. Kristo osteko XIV. mendean beira lantzen zuten artisauek zilar- eta urre-kantitate txikiak nahasten zituzten kolorazio ezberdinak lortzeko helburuz. Geroago eginiko azterketek berretsi zuten lortzen ziren koloreen erantzuleak erabilitako metalen nanopartikulak zirela, quantum dot gisa jokatzen zutenak [4]. Baliteke gizakiak nanoteknologiarekin eginiko lanik garrantzitsuena Kristo aurreko IV. mendeko Likurgoko kopa izatea, Londreseko Britaniar museoan ikus daitekeena. Artelan hori 5-60 nm-ko zilar- eta urre-nanopartikulez osatua dago; horren ondorioz kopak argia islatzen duenean berde ikusten da, eta argiak zeharkatzen duenean, berriz, gorri [5].

Oro har, nanopartikulek dituzten propietate ikusgarriak bi efekturen erantzule direla jotzen da. Alde batetik, kuantu-efektuak, egitura elektronikoan gertatzen diren aldaketekin erlazionaturik daudenak, hala nola konfinamendu kuantikoarekin jazo diren energia-maila aldaketak. Efektu horien adibide dira tamaina eta erantzun magnetikoaren araberako kolore aldaketak. Bestalde, efektu klasikoak aurkitzen dira, non partikulak zenbat eta 
txikiagoak izan, orduan eta erreaktiboagoak, azkarragoak, eta datuak metatzeko ahalmena handiagoa duten. Izan ere, objektu baten tamaina txikitzen doan heinean, gainazalean egongo diren atomoen proportzioa handiagoa izango da barruan daudenekin alderatuz. Beraz, gainazaleko eta barruko elektroiek propietate ezberdinak dituzte. Errazagoa da gainazalean dagoen elektroi bat mugitzea barruan dagoena baino. Elektroiek materialean zehar bidaiatzen dute eta haien abiadura material motarekin zuzenki erlazionatua dago. Partikularen tamaina txikitzen denean elektroiak egin beharreko ibilbidea ere txikitu egiten da.

Azaldutako azken efektu hori gainazal-bolumen erlazioarekin lotuta dago, eta elikagaien industrian garrantzia gehien duen efektua da. Nanoteknologiak elikagaien industrian dituen aplikazioen arabera hiru sektoretan sailkatzen da: (i) osagaiak, gehigarriak eta elikagai osagarriak, (ii) elikagaien biltegiratzea, eta (iii) nano-sentsoreak.

\section{NANOTEKNOLOGIA ELIKAGAIEN INDUSTRIAN}

Aipatu den bezala, azken hamarkadetan, nanoteknologiaren inguruko ikerkuntzek aurrerapauso handia eman dute eta horren harira, argitaraturiko artikulu bibliografikoen kopuruak gora egin du. «Scopus» (www. scopus.com) datu basearen arabera, «nanotechnology» hitza 1978. urtean aipatu zen lehen aldiz. Bertan eginiko ikerketan, nanosegundotan lan egiten zuen X-izpi detektagailu baten propietate fluoreszenteak aztertzen ziren [6]. Bi hamarkada geroago, 1995ean, elikagaiak eta nanoteknologia batzen zituen lehen artikulua argitaratu zen. Artikulu horretan, adimenduna zen sistema molekular bat garatu zen, molekula biologiko ezberdinak bereizteko gai zena [7]. Guztira, posible da 138.516 artikulu aurkitzea, horietatik soilik 10.000 inguru elikagaiekin nolabaiteko zerikusia dutenak. 1. irudian aurkezten dira, «nanotechnology» hitzarekin argitaraturik dauden artikulu guztiak, eta 2. irudian, aldiz, elikagaien zientzian, nanoteknologiarekin erlazionatzen direnak. Bi kasuetan ikus daitekeen joera nahiko antzekoa da, baina 10 urteko atzerapenarekin elikagaien kasuan. Horren arrazoia nanosistemen toxikotasunaren edo segurtasunaren inguruko ezjakintasunak kontsumitzaileengan sor dezakeen kezkarekin erlazionatua egon daiteke. 


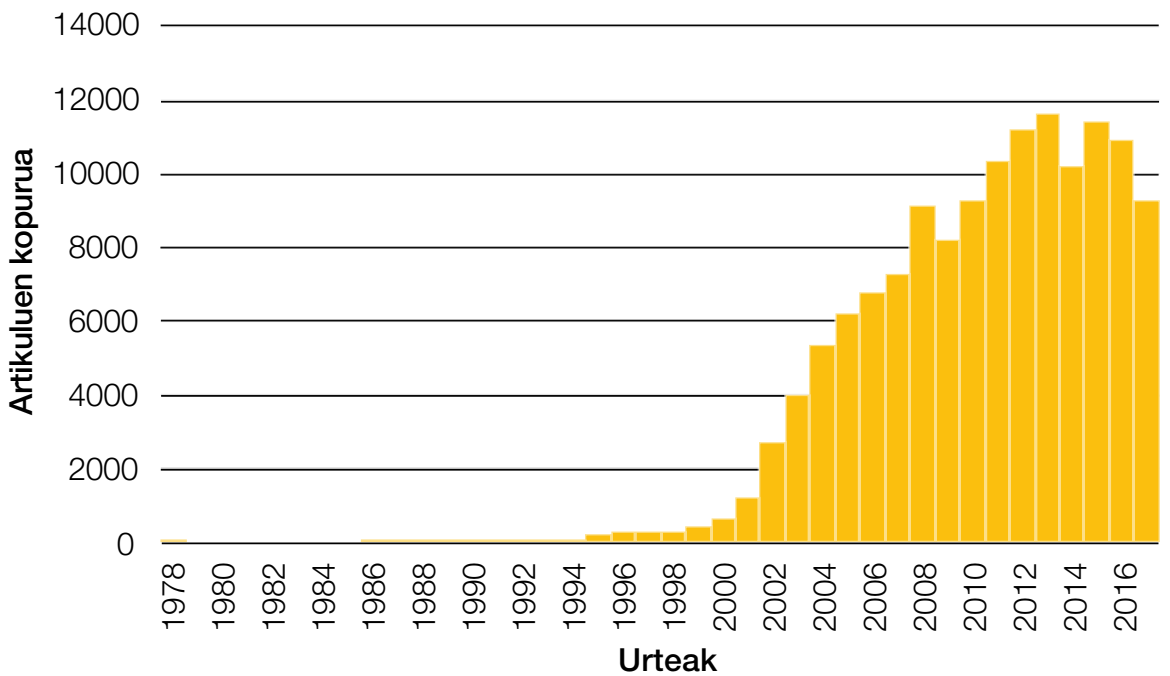

1. irudia. Nanoteknologiarekin erlazionaturiko artikulu kopuruen garapena, urtez urte. Scopus datu basetik jasotako datuak. (2018ko urtarrilaren 16an berrikusitako datuak).

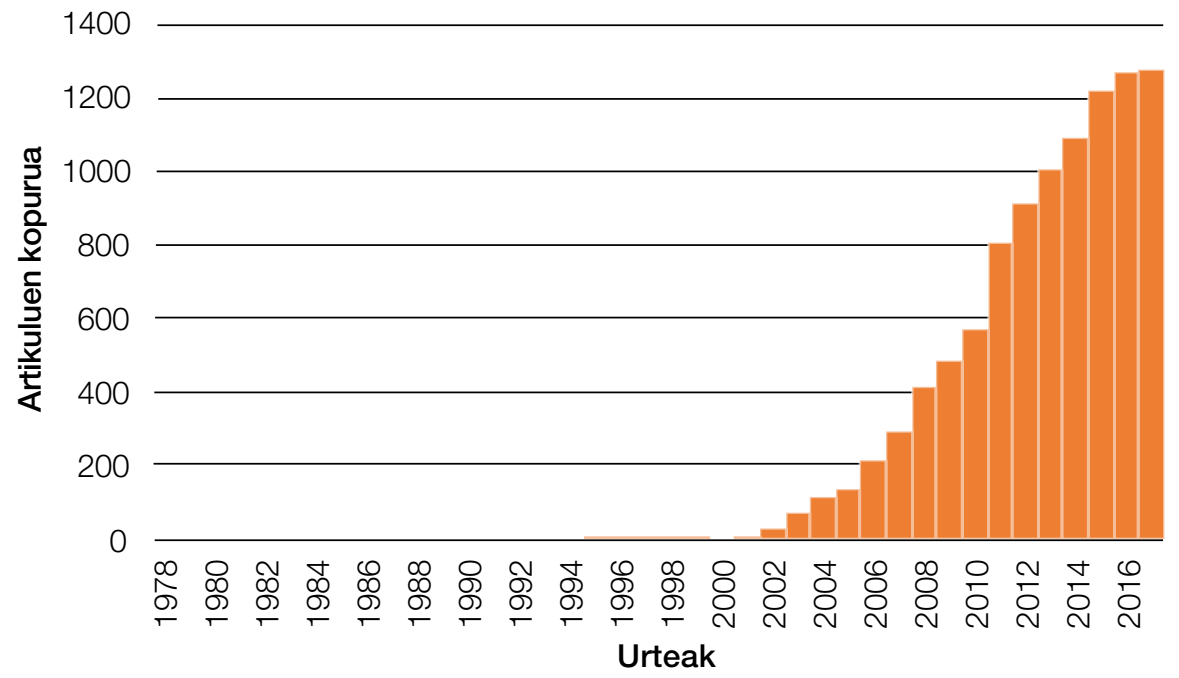

2. irudia. Nanoteknologia elikagaien sektorearekin erlazionaturiko artikulu kopuruen garapena, urtez urte. Scopus datu basetik jasotako datuak. (2018ko urtarrilaren 16 an berrikusitako datuak). 
1. eta 2. irudietan ikus daitekeen moduan, azken hamarkadetan nanoteknologiaren inguruko interesa asko hazi da. Horrekin batera enpresa asko azaleratu dira, hala nola nanoteknologian espezializatu direnak eta terapietarako, mediku diagnosietarako, energia-produkziorako edo molekulen sintesirako material nanometrikoak sortzen dituztenak. 2008. urtean, 15 mila milioi dolar inbertitu ziren mundu osoan gai horren ikerkuntza eta garapenerako (sektore publiko zein pribatutik). Garapen horrek 400.000 lanpostu sortu ditu mundu osoan. 2020 urtean nanoteknologiak mundu-ekonomian 3 bilioiko inpaktua izango duela aurreikusten da, eta, horretarako, 6 milioi langile beharko dira [8]. Aurkeztutako guztiarekin, eztabaidaezina da nanoteknologiak gaur egungo eta etorkizuneko gizartean izango duen inpaktua. Aldi berean, elikagaien industria etengabe dabil produktuen zaporea, usaina ala iraupena hobetuko duten teknologia berrien bila. Gainera, gure gizartea gero eta kontzientziatuago dago elikagaiekin erlazionaturik dauden gaixotasunekin. Ondorioz, hondakin- eta karbono-aztarnak murriztu nahian, industria sektoreak esfortzu handia egiten ari dira beren produktuen elaborazioan gatz, azukre, gantz, koloratzaile eta kontserbatzaileen kantitatea murrizteko [9]. Horren harira, interes handia piztu da diabetesa, digestio alterazioak, gaixotasun kardiobaskularrak, gizentasuna eta beste gaixotasunak tratatzeko elikagai berezien garapenean. Gainera, beharrezkoa da elikagaien ontziratzea garatzea, birziklagarriak izatea, argiarekiko erresistenteak eta indartsuagoak [10]. Ondorioz, gizartearen eskakizunak asetzeko nanoteknologiak paper garrantzitsu bat bete dezake egungo eta etorkizuneko elikagaien industrian [11].

Gaur egun nanoteknologia hiru alorretan banatzen da elikagaien industriaren barnean: gehigarri bezala, ontzietan eta sentsore bezala, elikagaien egoerari edo baldintzei buruzko jarraipena egiteko $[12,13]$. Jarraian, nanoelikagaien inguruan emandako aurrerapauso garrantzitsuenak aztertzen dira, kontuan izanik «nanoelikagaia» hitza erabiltzean nanopartikulez osaturiko elikagaiei eta haien produkzioan erabili direnei egiten zaiela erreferentzia.

\subsection{Osagaiak, gehigarriak eta elikagai osagarriak}

Elikagaiak, proteinaz, gantzez eta karbohidratoz osaturiko egitura biologiko konplexuak dira. Osagai horiek guztiak ere nanosustantzia bezala defini daitezke (beti ere haien dimentsiotako batek $100 \mathrm{~nm}$ baino gutxiago baditu) [14]. Miosina adibide gisa har dezakegu, haragietan aurkitzen den proteina haritsu bat da eta aktiniarekin batera muskulu-uzkurdura eragiten du. Proteina horrek 1,5 $\mu \mathrm{m}$-ko luzera eta $15 \mathrm{~nm}$-ko diametrodun filamentuz dago osatua. Nanosustantzia horiek automihiztatzeko ahalmena dute eta ordena handiagoko egiturak sortzen dituzte. Kontuan izanik elikagaiak nanoegituraz osaturik daudela, atal honetan nanopartikulen eta nanomaterialen inguruko sarrera egingo da, elikagaien osagai naturalak alde batera utziz. Nanoegituren inplementazioaren xedea propietate osasuntsu berriak lortzea da, hala nola organismoan osagaien atxikipena, absortzioa eta bioe- 
rabilgarritasun hobea izatea. Era berean, 1. taulan aurkezten den bezala, zaporea, testura eta nutrizio-balioak ere hobetu behar dira [15].

Garapenaren ildo nagusia balio altuko elikagaien lorpenean zentratzen da eta ondoko helburuak ezartzen dira:

- Gatzak, gantzak eta beste gehigarriak murriztea elikagai osasuntsuagoak ekoizteko.

- Elikagaien kolorea, zaporea, testura edo dentsitatea eta beste propietateak hobetzea.

- Zaporeen eta osagaien askapena kontrolatzea, nutrienteen absortzioa hobetzea organismoan.

Etorkizunerako helburu nagusia kontsumitzaileak bere beharren arabera aldatzea posible izango den nanoelikagai bat sortzea da. Horren adibide bat kolore eta zapore gabeko edari bat izango litzake, non nanokapsulatutako eta nanogehigarriz osaturiko osagaiak egongo liratekeen, eta kontsumitzaileak kanpoko estimulu baten bitartez (adb. mikrouhinak) aktibatu ahalko lituzkeena. Horren bidez, estimulu konkretu baten bidez nanokapsula batzuk aktibatu egingo lirateke, eta besteak egonkor mantendu; izan ere, kanpoko estimulua modulatuz, elikagaiaren propietateak aldatzea bideragarria izango litzateke. Nanokapsula horiek elikagai funtzionalez osaturik egon daitezke (farmakoak, bitaminak, antimikrobiarrak, antioxidatzaileak, zaporeak, koloratzaileak, kontserbatzaileak...), funtsezkoak diren hainbat produktutan [16]. Osagai funtzional horiek askapeneko nanosistemetan txertatzen dira, arraroa izaten baita haien erabilera forma puruan. Askapen sistema horiek ezaugarri minimo batzuk bete behar dituzte, hala nola garraiatzeko ahalmena, degradazio biologikoetatik zein kimikoetatik babesteko gai izatea eta askapen-prozesua kontrolatzeko gai izatea $[17,18]$. Azkenik, bateragarria izan behar da gainerako konposatuekin eta produktuaren propietateekin (itxura, testura, zaporea ala iraupena). Askapen-sistema egokia aukeratzeak berebiziko garrantzia du osagai funtzionalen eraginkortasunerako. Horren harira, osagai funtzionalentzako kapsulazio-sistema desberdinak daude. Sistema garatuenen artean honako hauek nabarmentzen dira:

- Asoziazio koloidalak (mizelak eta besikulak): haien formazioa egiteko surfaktanteak erabili ohi dira. Formazio hori espontaneoki gertatzen da; izan ere, sistema termodinamikoki faboratua dago. Normalean disoluzio gardenak lortzen dira, eta haien desabantaila nagusia surfaktante kantitate handia behar dela da. Horrek arazoak sor ditzake zaporearekin, kostuarekin eta legalitatearekin.

- Nanoemultsioak: presio altuko homogeneizatzaileak erabiliz $100 \mathrm{~nm}$-ko diametroa baino txikiagoa duten tanta-emultsioak lor daitezke. Osagai funtzionalak tanta horietan barneratuz osagaien degradazio kimikoa atzera daiteke. 


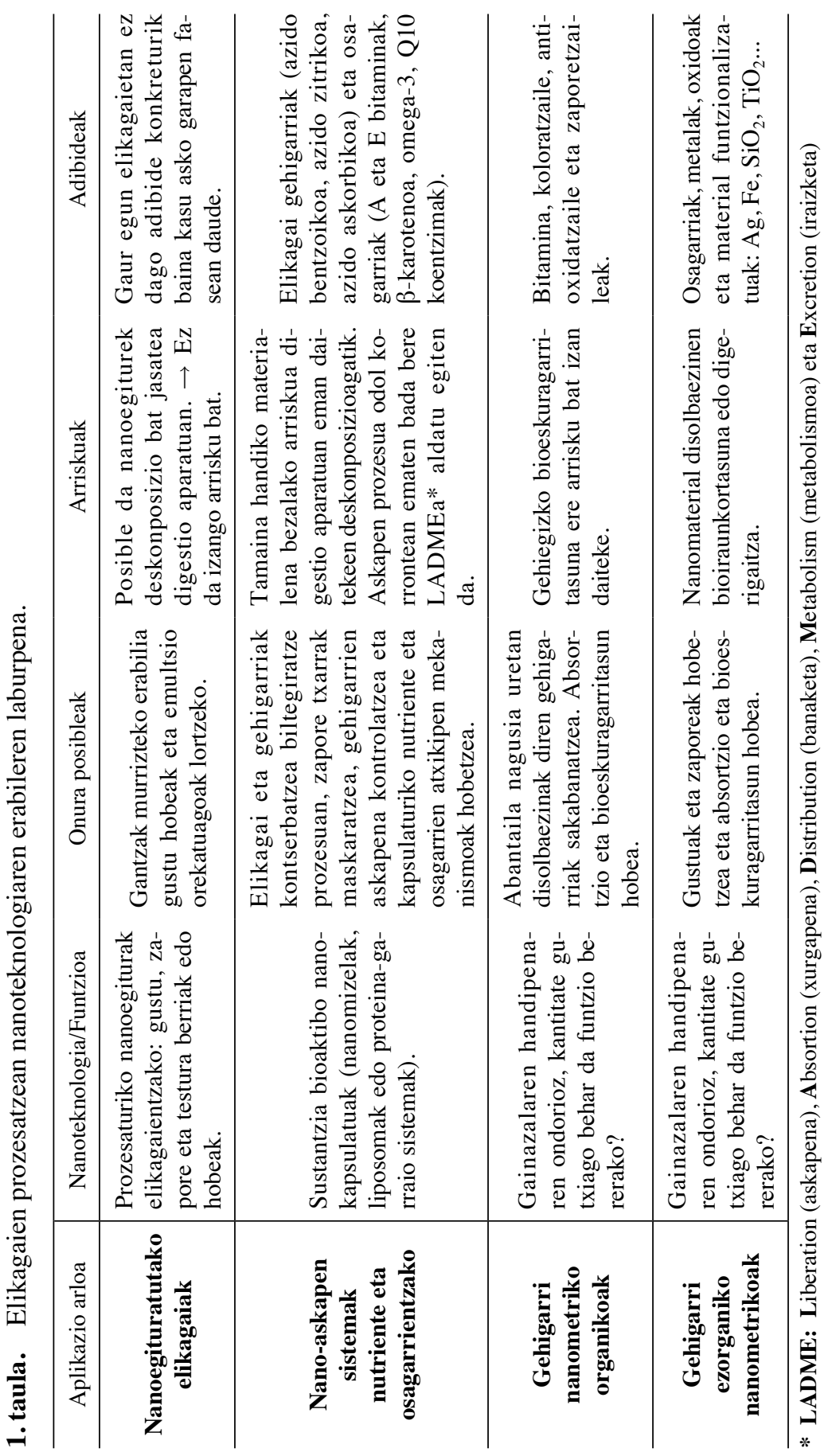


- Multifasedun nanoemultsioak: ohikoenak olioa/ura/olioa eta ura/ olioa/ura dira eta osagai funtzionala edozein fasetan barnera daiteke. Are gehiago, sistemak horiek osatzen dituzten fase bakoitzak osagai funtzional ezberdinak barneratzeko gaitasuna eskaintzen dute, osagai bakoitzaren askapen lekua hautatzeko aukera eskainiz.

- Multigeruza nanoemultsioak: kasu honetan elkarreragin elektrostatikoen bidez erakarriak diren polielektrolitoz gaineztatutako nukleo oliotsuak erabiltzen dira. Ekoizpen-prozesuak «geruzaz geruza» (ingeleseko layer-by-layer) du izena. Sistema horiek nukleoari ingurune desberdinekiko egonkortsuna handitzen du eta, gainera, nukleoko osagai funtzionalaren askapena kontrolatzeko gaitasuna dute. Sistemaren ingurunean pHaren edo indar ionikoaren aldaketek gainazalaren disoziazio osoa zein partziala eragiten dute eta nukleoaren askapena burutuz.

- Nanoijezketak: fisikoki edo kimikoki lotutako nanomaterialaren bi edo geruza gehiagoz osatuta dago. Material horiek prestatzeko gehien erabiltzen den metodoa geruzaz geruzako prozesua da. Ijezketa horiek oztopo sistematzat erabili daitezke, elikagai bati ehundura zehatza emateko edo osagai funtzionalak garraiatzeko.

Sistema horiek kontrolatutako askapenerako eta konposatu bioaktiboak babesteko erabiltzen dira. Garrantzitsua da nanokapsulen eta nanoesferen artean desberdintzen jakitea. Lehenengoaren kasuan, sistema besikularra da eta konposatu bioaktiboa txertaturik aurkitzen da horma polimeriko baten bitartez bildurik. Bigarrenaren kasuan, konposatu bioaktiboa uniformeki sakabanatuta aurkitzen da.

Nanokapsulazio prozesuan nutrazeutikoen bioeskaintza hazi egiten da nanogarraiatzaileak odol korrontearen barnean hesteetatik sarrera errazten duen heinean. Horren harira, nanogarraiatzaile lipofilikoek (likopenoa, $\beta$-karotenoa, luteina, fitosterolak, DHA...) askapen partziala aurkezten dute eta hesteetako paretekiko nahiko iragazkorrak dira. Hidrofilikoetan, aldiz (azido askorbikoa, polifenolak...), askapen abiadura azkarragoa da [19].

Nahiz eta nanokapsulazio eta askapen nanosistemak nahiko garatuak dauden, merkatuan oso produktu gutxik adierazten dute haien konposizioan nanomaterial aktiboen presentzia. Aurrerago aztertuko den bezala, farmakoen industrian nanopartikulen erabilera oso zabaldua dagoen arren, elikagaien industrian gaur egun zailtasunak dituzte atal komertzialera salto egiteko, nahiz eta garapen jarraituko sektorea den.

\subsection{Elikagaiak paketatzea}

Gaur egun, elikagaiak gordetzeko erabiltzen diren ontzi gehienak ingurumenaren kutsadura eta erregai fosilen kontsumoa bultzatzen dituzten 
material ez berriztagarriz eginda daude. Azken urteetan, ohiko plastikoak baztertuko dituzten material biodegradagarriak ekoizteko ahalegin handiak egin dira, baina oraindik ez dira oso arrakastatsuak izatera heldu. Izan ere, sortutako material polimeriko berrien propietateak (mekanikoak zein hesipropietateak) ez dira oso onak izan. Zentzu horretan, propietate mekaniko, termiko eta gasekiko iragazgaiztasun hobeak dituzten nanoegituratutako material hibrido berriak sortu dira. Material berri horiek elikagaiak babesten dituzte, iraungitze-data luzatzen baitute, eta, aldi berean, paketatzeko erabiltzen diren plastikoen beharra txikitzen dute, hala konponbide ekologikoagoa izanik $[20,21]$. Nanoteknologiak elikagaien paketatzean dituen aplikazio nagusiak askotariko sistematan nanomaterialak eranstean datza, hala nola biodegradazioa, gas edo lurrunen aurreko iragazgaiztasuna, iraunkortasuna eta propietate fisikoak hobetuko dituen nanokonpositeak; hesi-propietateak hobetuko dituzten ontzien (barnealdea zein kanpoaldea) gainazalaren nanoestalketa; gainazal biozidak sortzea, non mikroorganismoen kontrako propietateak dituzten nanopartikulek ontziaren gainazalean lan egiten duten; mikroorganismoen zein oxidazioaren kontrako propietateak dituzten eta era kontrolatuan askatzen diren nanomaterialak dituzten ontzi aktiboak eraikitzea. Jarraian, nanomaterialekin hobetutako materialak prestatzeko dauden bi teknika garatuenak azalduko dira.

\subsubsection{Hesi-propietateak hobetzeko nanoegituradun polimeroak.}

Ezer baino lehen, elikagaiak gordetzen dituzten ontzien migrazio eta iragazkortasun fenomenoak aipatzea ezinbestekoa ikusten da. Izan ere, gasatmosferikoekiko, ur-lurrunarekiko edo elikagaietan egon daitezkeen beste sustantziekiko erabateko iragazgaiztasuna duen materialik ez da ezagutzen. Kasu batzuetan, barazki zein fruitu freskoak paketatzean, adibidez, ez da gomendagarria gasekiko erabateko iragazgaiztasuna izatea. Beste kasu batzuetan, aldiz, elikagai gehienen paketatzean oxigeno fluxu kontrolatua izateak hobe ditzake jakien iraunkortasuna, kalitatea eta segurtasuna. Tradizioz, metala, beira eta papera izan dira elikagaiak paketatzeko erabili diren materialak. Nahiz eta material horiek oraindik erabiltzen diren, polimeroek aurkeztu dituzten arintasunak (pisu baxua), kostu merkeak, prozesatze erraztasunak eta propietate fisiko anitzek elikagaien paketatze sistemetan erabiltzeko material oso erakargarriak bihurtu dituzte. Hortaz, gaur egun gehien erabiltzen diren polimeroak polipropilenoa (PP) eta gisako poliolefinak, polietilentereftalatoa (PET) eta halako polietilenoak, poliestirenoa (PS) eta polibinil kloruroa (PVC) dira [22]. Polimero horiek hainbat abantaila erakusten dituzte material tradizionalekin konparatuz, baina gasekiko eta beste molekula txikiekiko duten iragazkortasunarekin erlazionatutako desabantailak ere badituzte. Polimero bakoitzak, bere ezaugarrien arabera, oxigenoarekiko iragazkortasun desberdina aurkezten du. Ezaugarri horiek, besteak beste, honako hauek dira: alboko kateen egitura ezaugarriak eta polaritatea, 
hidrogeno-loturarekin erlazionatutako ezaugarri polimerikoak, pisu molekularra, kateen adarkatze eta erretikulartasuna, polimeroaren prozesatze metodologia, sintesi metodoa eta kristalizazio-maila. Oro har, elikagai paketatze bakoitzerako ezin hobea izan daitekeen polimero pururik ezagutzen ez denez, polimero-nahasketak edo geruza anitzeko film konplexuak erabiltzen dira. Nanomaterial polimerikoak (edo nanokonpositeak) erabiltzen ari dira ontziratze-sistemen hesi-propietateak hobetzeko. Material horiek ekoizteko, bi bide desberdin jarrai daitezke: i) material polimerikoak nanoeskalan fabrikatzea edo ii) nanoegituradun materialak jatorrizko matrizean sartzea. Azken hori da gaur egun erabiltzen den metodo nagusia, eta geldoa den material nanometrikoa matrize polimerikoan sakabanatuz fabrikatzen da. Normalean, erabiltzen dira buztinak (montmorillonita, silikatozko nanofilmez osatuta dagoena, gehien erabiltzen dena da), silizezko nanopartikulak, karbonozko nanotutuak, grafenoa, almidoizko nanokristalak, zelulosazko nanozuntzak edo nanotutuak, kitosano nanopartikulak edo beste molekula ezorganikoak $[23,24]$. 3. irudian nanobuztinen ekintzen eskema aurkezten da:

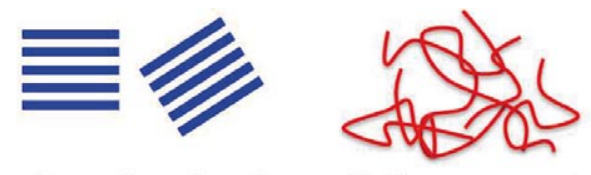

Xafla egitura duen buztina Polimeroa, proteina

Lodiera $\sim 1 \mathrm{~nm}$

$$
\text { edo karbohidratoa }
$$

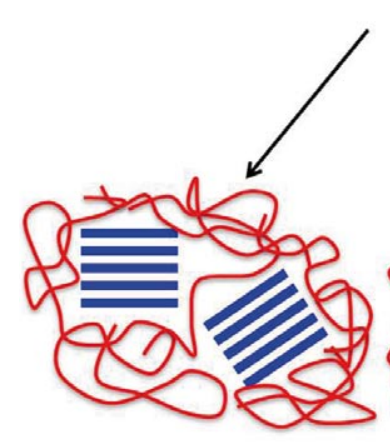

Faseak bananduta (mikrokonpositea)

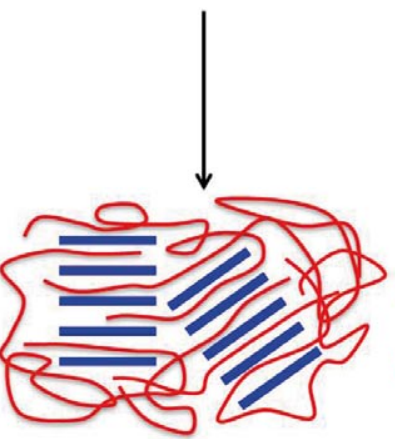

Tartekatutako faseak (nanokonpositea)

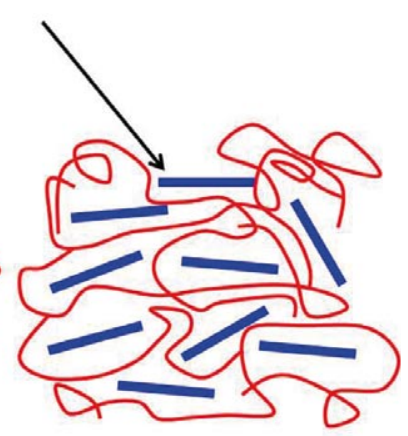

Esfoliatutako faseak (nanokonpositea)

3. irudia. Gehien ikertutako nanokonposite sistemaren eskema: montmorillonita eta halako gehigarri organofilikoa betegarritzat erabiltzen duen matrize organikodun material hibridoa. [25]-tik egokituta.

Gehigarri nanometrikoak, materialean \%5eko kontzentrazioa baino txikiagoa duena, matrizea indartzeaz gain, nanokonpositeari malgutasuna, 
oztopo propietateak, tenperatura kontrolatzeko aukera eta egonkortasuna ematen dizkio [26]. 4. irudian polimero batean nanokonpositeak gehitzean gasek polimeroan zehar garraiatzeko topatzen dituzten oztopoak ikus daitezke.

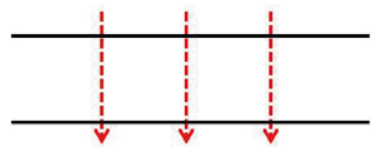

Polimero konbentzionala

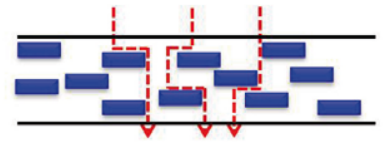

Orri-egituradun silikato eta polimeroaren arteko nanokonpositea

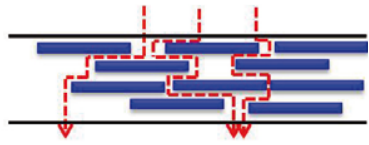

Itxura-erlazio handiko nanokonposite polimerikoa

4. irudia. Matrize polimerikoan buztin xaflak tartekatzean gasek aurkitzen dituzten oztopoak irudikatzen dituen eskema. Polimeroz bakarrik osatutako filmean (ezkerrean), gas molekulen difusioa filmarekiko guztiz perpendikularra da. Nanokonposatuetan (erdian eta eskuinean), molekulek iragazkortasun ezaugarri desberdinak dituzten partikulen artean garraiatuak izan behar dute. Oztopo horiek gasaren garraio denbora eta, horrenbestez, elikagaien iraupena luzatzen dute.

Hesi-propietateak hobetzeaz gain, nanoegiturarik ez duten polimeroen ezaugarri berdinak edo hobeak dituen nanokonpositedun polimero kantitate txikiagoak erabiltzea lortu da eta posible egin da ontzien pareten lodiera mehetzea. Horrek ekoizpen-gastuak merkatzea eta hondakinen-kantitatea txikitzea eragiten du. Hauek dira film polimerikoen iragazgaiztasuna baldintzatzen duten kondizioak: egituretan duten hutsune libreak, bolumena, polimeroaren mugikortasun gradua, polimero-polimero elkarrekintzak eta kanpoko baldintza atmosferikoak (presioa eta tenperatura) .

\subsubsection{Agente antimikrobianodun nanopartikulak}

Urte asko pasa dira landareen propietate antiseptikoak eta sendagarriak aurkitu zirenetik. Kongregazio katolikoen kideen artean bakterioen zabalpena saihesteko, ardoa partekatzeko erabiltzen zituzten kalizen barnealdea zilarrez estalita zegoen. Bigarren Mundu Gerran zaurien infekzioa saihesteko zilarra erabiltzen zen. Zilar nanopartikulen aurkikuntzatik, elementu horren erabilerak gora egin du, eta egunero erabiltzen ditugun eguzki krema zein ontziratze-produktuetan agertzen da [27]. Ospitaleetan gaixotasunen hedapena saihesteko, paretetako margoekin batera nahastua ere aurkitzen da. Gainera, hozkailuen barneko estalkietan elikagaien kontserbazioa hobetzeko ere erabiltzen da. Arropetan ere ager daiteke, bakterioek sor dezaketen usain txarrak saihesteko. Baina zilar nanopartikulek beste aplikazio ugari dituzte; adibidez: sentsore kimikoetan, gaixotasunak detektatzeko gailuetan eta minbizia eta halako gaixotasunen tratamenduan $[28,29]$. 
Esan bezala, zilarrak dituen bioziden eta mikroorganismoen kontrako propietateei esker asko erabili da elikagaien ontziratze sektorean. Agente biozidak, elikagaiaren gainazala egoera higieniko onean eutsiz, elikagaian ager daitezkeen mikroorganismoen hazkuntza saihesten du. Agente biozidek paper garrantzitsua izan dezakete in situ garbiketa egitea zaila den elikagaien prozesatze (hegaztien abeletxeetan) zein elikagaien manipulatze (zinta garraiatzaileetan) ekipoetan. Aldi berean, berrerabili daitezkeen kutxetan zein hozkailuen barne lerroetan erabili daitezke [30].

Bestalde, zilarrak mikroorganismoen aurka erakusten duen izaerari esker, elikagaien ezaugarriak eta iraungitze-data hobetzeko gaitasuna duen paketatze sistema aktiboa diseina daiteke. Bide horretatik, abantaila asko aurkezten ditu andui bakteriano, alga eta onddo askorekiko zilarrak dituen toxizitate-maila desberdinak eta espektro zabalak mikrobioen aurka erabiltzen diren beste agenteekiko. Gainera, materialetan (ehunak, plastikoak...) modu errazean sartzeko aukera emateaz eta gizakientzako segurua izateaz gain, zilarra oso egonkorra da denboran. Asko izan dira zilar nanopartikulek mikrobioen aurka daukaten izaera berezia azaldu nahi izan dutenak, baina komunitate zientifikoak oraindik ez du akordiorik lortu. Dena den, zilarrak mikroorganismoen kontra duen izaeraren azalpen guztiak orokorrean bat datoz eta honako mekanismo hauetariko batek eraginda sortzen da [31]:

- Proteinen zein beste entzimen mintzen gainazalean sulfhidrilo (-SH) edo disulfuro (-SS-) talde funtzionalekin eratutako loturek oinarrizkoak diren prozesu zelularretan eragindako interferentzia.

- DNAren erreplikazio prozesuaren etena. Zelulak, defentsa mekanismo gisa, DNA kondentsatu egiten du.

- Katalisi bidez oxigeno espezie erreaktiboak (OEE) eratzeak eragiten duen estres oxidatiboaren ondorioz.

Zientzialariek gai honen inguruan aurkezten duten adostasun eza zilarraren hiru eragin prozesuetatik garrantzitsuena zein den erabakitzeko gaitasun ezan oinarrituta dago. Zilar nanopartikulen kasuan, nanopartikulen gainazaletik zilar atomoak askatzen direla eta kalte zelularra sortzen dutela uste da. Mikroorganismoen aurkako jarrera baldintza hauen baitan dago: zilar ioien askapen abiadura, polimeroaren kristalinitate-maila, polimeroan sartzen den material mota (hau da, zilarra, zeolitak, etab.), matrizearen hidrofobizitatea eta partikulen tamaina (nanokonposatu edo mikrokonposatuak diren, besteak beste). Baina, nahiz eta zilar nanoegiturak dituzten elikagai paketatze sistemetan aurrerapen handiak egin diren, material horiek oraindik ikerkuntza-mailan daude. Izan ere, mikrobioen kontra jarduten duten mekanismoak argitzeko lan asko dago egiteko [32]. Gaur egun, magnesio oxidozko, titanio dioxidozko, kobre oxidozko, karbonozko nanotutuak eta halako nanoegiturak ikertzen ari dira gainazal 
biozidetan jartzeko asmoz [33]. Nanoteknologian, gainazalen zein uraren esterilizazio fotokatalitikoa garatzeko nano-estalkietan ere lan egiten ari da. Horietarako, ultramore-C erradiazioarekin batera funtzionatzen duten titanio dioxidozko nanopartikulez osatutako gainazalak erabiltzen dira $[34,35]$. Sistema horietan, nahiz eta nanopartikulak elikagaiaren baitan ez dauden, tratatutako ontziratze materialarekin kontaktuan dago elikagaia. Horregatik, elikagaien kutsatzea saihesteko ezinbestekoa da ezagutzea paketatzeko erabili den materialaren migrazio-gaitasun prozesuak eta horiek estalkiaren propietate toxikoetan izan ditzaketen eraginak. 2014. urtean Cushen eta lagunek nanokonpositeetan zilarrak eta kobreak dituzten migrazio-propietateen inguruko eredu bat garatu zuten [36]. Zoritxarrez, eredu hori ikertutako sisteman baino ez da aplikagarria. Ondorioz, nanosistema bakoitzak dituen ezaugarri berezien ondorioz indibidualki aztertua izan behar da.

\subsection{Nanosentsoreak}

Paketatze-materialek esposizio sentsoriala (usain txarra, kolorea, ehundura...) saihesten dutenean, oso garrantzitsua da kontsumitzaileek elikagaien iraungitze-datari arreta jartzea. Izan ere, elikagaien garraio eta paketatzean oinarritutako datak dira eta horiek era desegokian eginez gero, produktua eraldatua izan daiteke eta kontsumorako era desegokian aurki daiteke. Nanoeskalan dauden partikulen propietate kimiko eta elektro-optikoek arazo horri aurre egiteko aukera eskaintzen dute. Nanomaterialek gasen presentzia, usainak, kutsatzaile kimiko eta patogenoen presentzia detekta ditzakete eta ingurumenean jasandako eraldaketei erantzuteko gaitasuna dute [37]. Sistema horiek kontsumitzaileek freskotasuna eta zapore optimoa duten produktuen kalitatea kontrolatzeaz gain, elikagaien bidez kutsatzen diren gaixotasunen hedapena txikitzen dute eta elikagaien segurtasuna hobetzen da.

Azken urte hauetan, oxigeno sentsoreekiko interesa handitu da, eraldatutako atmosferan paketatutako elikagaien ontzietan jartzen diren sentsorerena, batez ere [38]. Paketatze-metodo horrek elikagaiak inguratzen dituen atmosferan egon daitekeen airea kentzean edo ordezkatzean oinarritzen da. Metodo horren bidez, elikagaien freskotasuna denbora luzeagoan mantentzea lortzen da. Gaur egun, metodo hori barazki freskoen, fruten, haragien eta arrainen paketatze-ontzietan erabiltzen da. Ontziaren barnean dagoen oxigeno kantitatea txikitzean eta karbono dioxidozko eta nitrogeno kantitateak aldatuz elikagaien balio-bizitza luzatzen da. Alde batetik, oxigeno kontzentrazio altuek oxidazio prozesuak bultzatzen dituzte, baina oxigeno kontzentrazio txikiek arnaste tasa, etileno ekoizpena, iluntze entzimatikoa eta aktibitate metabolikoa murrizten dituzte. Karbono dioxidoak, bestalde, hazkuntza bakteriano aerobikoa galarazten du. Hortaz, interesgarria izango litzateke elikagaien ontzietan oxigenoa sartu den jakitea. 
Elikagaien paketatze sistemetan egindako aurrerapenak ikusita, gomendagarria izango litzateke oxigeno-adierazleen garapena berrikustea. Izan ere, oxigeno sentsoreak izan beharko lituzkeen propietate idealak ezagututa diseinu on bat gara daiteke. Lehenik eta behin, merkea izan behar du kontsumitzaile guztiek eskuragarri izan dezaten. Horrekin batera, edozein pertsonak erabili ahal izateko maneiatze-sistema erraza izatea gomendagarria da. Gainera, ezin da toxikoa izan eta haren osagaiak ezin dira uretan disolbagarriak izan, elikagaiekin kontaktua izanez gero haien kutsapena saihesteko. Horren harira, balio-bizitza luzea izan behar du eta paketatze-ontzia itxita eta oxigenorik gabe dagoenean bakarrik aktibatzeko gai izan behar da. Aldi berean, elikagai guztiek oxigenoarekiko sentikortasun desberdina dutenez, oxigenoarekiko duen sentsibilitate maila aldatzeko aukera izatea gomendagarria izango litzateke. Bukatzeko, adierazleak oxigeno kontzentrazio zehatzekiko duen erantzuna itzulezina izan behar da manipulazioa saihesteko [38].

Adierazleak bi kategoriatan sailka daitezke:

\section{a) Lumineszentzian oinarritutako oxigeno adierazleak.}

Ahultzaile dinamikoen bidez (oxigenoa, adibidez) luminoforo baten lumineszentzia seinalea ahultzean oinarritutako adierazle optikoak interes handia jasotzen ari diren taldeak dira. Sentsoreak lumineszentzia fenomenoaren intentsitate galeran zein fenomenoaren iraun denboran oinarrituta egon daitezke.

b) Kolorimetrian oinarritutako oxigeno adierazleak.

Adierazle mota honen kolore aldaketa fabrikazio prozesuan erabilitako materialen araberakoa izango da:

- Oxigeno molekularekin lotu daitezkeen konposatu konplexuetan oinarritutako adierazle kolorimetrikoak: asko izan dira aztertutakoak, baina bis(histidinato)kobalto(II) konposatua, $\mathrm{Co}(\mathrm{His})_{2}$, bideragarria dirudien bakarra da [39]. Konplexu metaliko horrek ez du kolorerik islatzen aske dagoenean, baina oxigenoarekin batzean kolore arrosa islatzen du. Jatorrizko konplexura bueltatzeko gaitasunak, kolore aldatze ikusezinak eta $\mathrm{pH}$ aldaketekiko duen sentikortasunak atmosfera aldatutako paketatze ontzietan erabiltzeko desegokia izatea eragiten dute.

- Redox koloratzaileak: Ageless EyeTM da ezagunena, metileno urdinaren erredox koloratzaile dena, eta ingurune alkalinoan glukosa erreduzitzeko gaitasuna duena. Ohikoa da 52 azido gorria edo antzeko beste koloratzaile ez erredoxa gehitzea arrosa koloreko hondoa ematearren [38]. Modu horretan, oxigenoaren presentzian kolore arrosa izatetik kolore urdina izatera pasatzen da. Kostu handiko 
materiala da, alde batetik, urarekiko iragazgaitza eta oxigenoarekiko iragazkorra den material batez estali behar delako, eta, bestetik, ingurune anaerobikoan gorde behar delako.

- Argiarekin aktibatzen diren erredox koloratzaileak: argiarekin aktibatzen direnez, ez dute biltegiratze anaerobikorik behar. Hala ere, argiarekiko (ikusgaia eta ultramorea) sentikorrak direnez, argirik gabeko lekuetan gorde behar dira. Argi ultramorearekin (UM) bakarrik aktibatzen diren sentsoreek indar komertzial handia dutela dirudi eta etorkizuneko ontzi adimenduen artean oso nabarmenduak izango direla uste da.

Nanoteknologiak batez ere azken adierazleen garapena bultzatu du. Material ikertuenen artean erradiazio UMaren bidez aktibatzen diren koloratzaile erredox bati lotutako $\mathrm{TiO}_{2}$ nanopartikulak nabarmentzen dira. Orain arte, elikagaien ontziratzearen funtzionamendu ona analizatzeko, 300-400 ontzi bakoitzetik ontzi baten kontrola egiten da. Prozesu hori, oso garestia eta luzea izateaz gain, estrapolatu ezin den metodoa da. Arazo horiek saihesteko, $\mathrm{TiO}_{2}$ nanopartikulak erabiltzea ikertu da. Izan ere, modu errazean eta edozein momentutan, elikagaien egoeraren monitorizazioa egiteko aukera eskaintzen dute [40]. Adierazle horien funtzionamendua 5. irudian azaltzen da:

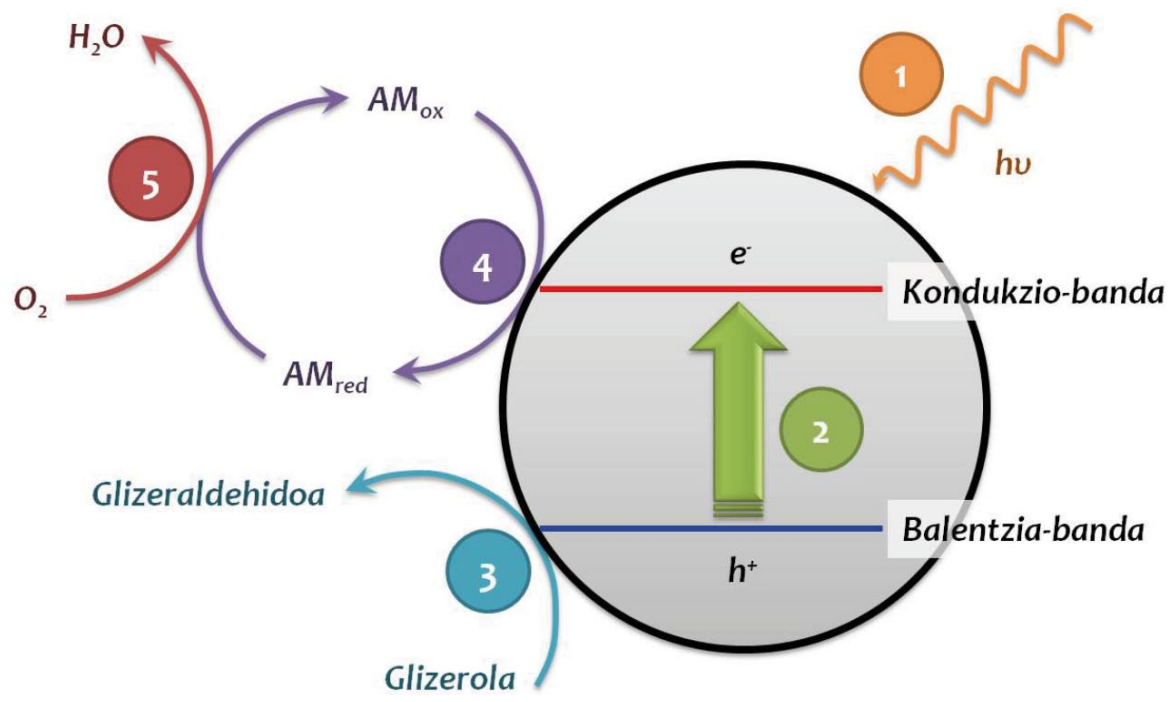

5.irudia. $\mathrm{TiO}_{2}$ nanopartikula fotoaktiboen erabilpenean oinarritutako oxigeno adierazlearen funtzionamendua erakusten duen eskema. [41]-tik egokitua.

Adierazlea argi UMarekin irradiatua denean (1. pausoa), balentzia geruzan dauden elektroiak kitzikatzen dira eta geruza eroalera mugitzen dira 
(2. pausoa). Ondorioz, $\mathrm{TiO}_{2}$ azpieroalearen gainazalean elektroi-hutsune bikoteak eratzen dira. Elektroiak ematen dituen substantzia batek (glizerola adibidez) balentzia geruzan interakzio fotonikoen ondorioz eratutako hutsuneei elektroiak emango dizkio (3. pausoa), kitzikatutako elektroiak hutsune horiekin birkonbina ez daitezen. Honek elektroi kitzikatuen pilaketa kondukzio bandan eragiten du eta elektroi horiek erabilgarriak izango dira koloratzailea (metileno urdina-MUox) erreduzitzeko (4. pausoa). Erreakzio horren ondorioz, koloratzailea erreduzitu egiten da eta koloregabea den MUred espeziea eratzen da (5. pausoa). Puntu horretan oxigeno adierazlea aktibatuta egongo da. Jarraian, adierazlea oxigenodun atmosfera batekin kontaktuan jarriz gero, MUred oxidatu egingo da eta kolore urdina berreskuratuko du. Urdin horren intentsitatea topatutako oxigeno kantitatearen araberakoa izango da. Ontzi mota horiek, atmosfera sentsoreak diren nanosistemadun pegatinak dituztenak, jada frogatuak izan dira eta emaitza oso onak erakutsi dituzte [42]. Elikagaien paketatze sistemetan kontrol-nanosistema berrien inplementazioan egindako azken aurrerapenek argi utzi dute produktoreentzako eta kontsumitzaileentzako abantaila asko dituztela. Hala ere, ikerketa goiztiar horren barnean ontziratze-sistema eta material berri hauen azterketa sakonagoak egin beharko dira benetako komertzializazioa izan aurretik.

\section{NANOELIKAGAIAK: AURRERAPENA EDO ELIKAGAI INDUSTRIARAKO ARRISKU ONARTEZINA}

Nahiz eta gaur egun nanoteknologiaren inguruan mirespen handia dagoen eta asko inbertitu den, elikagaien inguruan dagoen industria sektoreak medikuntza eta halako beste sektoreek baino denbora gehiago beharko du material mota horren aplikazio erreala egiteko. Baina hori ez da hain arraroa, gizarteak historikoki elikagai naturalekiko izan duen lehentasunak sortu berri diren elikagai teknologien erabilpena galarazi baitu beti. Orain, nanoteknologiaren aplikazioarekin gauza bera gertatzen da. Gainera, nahiz eta populazioak nanoteknologiaren erabilpenarekiko ikuspegi neutroa edo positiboa duen, ikerketa batzuek iradokitzen dute kontsumitzaileak «nanoelikagaiekin» kontu handiz ibiltzen direla [43]. Momentu honetan, nanoteknologia aplikatzeko dagoen elikagaien industria-sektore garatuena elikagaien paketatze sektorea da.

Nahiz eta medikuntza eta gisako beste sektoreetan nanoteknologiaren erabilpena oso garatua dagoen, elikagai industria oraindik bere lehen pausoak ematen ari da nanoteknologiaren aplikazioan. Material berri horien erabilpenak elikagai industrian iraultza berri bat sortuko dutela uste da. Teknologia berri honek ontziratze-ezaugarrien hobekuntza bideratuko du eta gasekiko oztopo propietate efizienteagoak aplikatuko ditu. Horren helburua produktuen kalitatea, balio-bizitza, segurtasuna eta trazabilitatea 
hobetzea da. Merkatuan dauden beste metodoekin konparatuz, orokorrean aparatu handiak direnak eta in situ detekzioa posible egiten ez dutenek, nanomaterialek erabiliz, eskuragarri izango dituzte kontsumitzaileei modu errazean elikagaien egoera eta kalitatearen berri emango dieten irakurketa (kolorimetrikoak, adibidez) metodo oso fidagarriak. Horrekin batera, nanomaterialak edozein matrizetan barneratzeko gaitasuna dutela-eta, eta elikagaiekin kontaktuan egoteko beharrik ez dutela kontuan izanik, etorkizun laburrean ekonomikoak eta tamaina txikikoak diren sentsoreak erabiltzeko aukera egongo da. Hortaz, etorkizun laburrean produktuaren kalitatea (deskonposizio zein kutsadura egoera) adierazteko, iraungitze-data izateaz gain, posible izango da kontsumitzaileek elikagaiaren ontzian bertan integratutako eta koloreen bidez kodifikatutako sentsoreak izatea. Nanoteknologia elikagaien paketatze-sistemetan integratzeko dagoen lehia horretaz gain, egia da nanoteknologiaren erabilpenean oinarritutako ontzi adimendunen aplikazio industrialerako asko ikertu behar dela oraindik. Helburu hori lortzeko, nanopartikulen toxizitatea (ioi metaliko toxikoen askapena, adibidez), ekotoxizitatea, birziklapena (nanopartikulak dituzten plastikoak) eta elikagaietan nanopartikulak erabiltzeko erregulazioa garatu eta aztertu behar dira. Gainera, gizartean nahiko hedatuta daude ontzi-elikagaietan kontaktuaren ondorioz eman daitezkeen migrazio prozesuekiko beldurra eta ingurumenean ontziek eragin ditzaketen kalteak zein inpaktuak. Gaur egun, nanoelikagaien etiketazioaren inguruan eztabaida handia sortu da. Izan ere, etiketatze horrek nanosistemak erabiltzea edo debekatzea kontsumitzailearen esku utziko luke. Komunitate zientifikoak, nanopartikula eta elikagaien artean egon daitekeen kontaktuaren ondorioz, defendatzen du nanoteknologiaren toxizitatearen inguruko ezagutza handiagoa behar dela. Berez, gaur egun existitzen den kezka nagusienetako bat $\mathrm{TiO}_{2}$ eta halako nanomaterialen erabilpenak eragin dezakeen genotoxizitatea da. Arazo nagusia oso sinplea da: nanopartikulak elikagai industrian erabiltzeko idealak egiten dituzten propietate berak kaltegarriak izan daitezke giza osasunerako. Gainera, nanosistemaren propietateak (toxizitatea barne) sistemaren konposizioa, partikula tamaina edo morfologiarekin batera alda daitezke. Argi dago nanosistemen toxizitate mekanismoak ulertzea ezinbestekoa dela, baina ez luke nanoelikagaien garapena gelditu beharko. Populazioak gora egin ahala, elikagaiak ondare geroz eta preziatuagoak bilakatu dira eta produkzio prozesuetan iraunkortasuna gero eta garrantzitsuagoa da. Hori dela eta, etorkizuneko paketatze ontzietan elikagaien degradazio prozesuen adierazle izan daitezkeen nanomaterialen erabilpena posible ikusten da. Modu horretan, elikagaien deuseztatzea txikitu eta superelikagaien (nutrizio kalitate handiko elikagaiak) agerpena garatuko dira. Ondorioz, ezinbestekoa da material horien toxizitatea ikertuko duen plataforma eratzea, non giza kontsumora bideratu aurretik nanomaterialen egokigarritasunaren eta neurri erregulatzaileen inguruan garatutako ezagutzak partekatuko diren. 


\section{ONDORIOAK}

Nanoteknologiaren erabilpenak sektore askoren aurrerapena bultzatu $\mathrm{du}$, besteak beste elikadura sektorean. Zentzu horretan, elikagaien paketatze-sistemetan nanoegituratutako konpositeen erabilerak, oztopo sistema efizienteagoak garatzeaz gain, elikagaiei babes handiagoa ematen dieten mikrobioen aurkako nanopartikulak eranstea ere posible egiten du. Aldi berean, nanosentsoreetan egindako aurrerapenek elikagaien egoeraren berri ematen duten indikatzaile talde berri baten agerpena eragin dute. Modu horretan, elikagaien iraungitze-data ezagutzeaz gain, posible izango da elikagaiak egoera optimoetan gorde eta garraiatu diren jakitea. Azkenik, nanogehigarriak (funtzionalak diren osagaiak, adibidez) kapsulazioaren bidez eransteak elikagaien balio-nutrizionalak zein elikagaien ehundura edo zaporea eralda ditzake. Aipatutako azken ikerketa eremu hori, nanoelikagaiena, biztanlerian eragin handienekoa da. Hala ere, nanoelikagaien komertzializazioak arazo handi batekin topo egin du: nanoteknologiaren pertzepzio publikoa. Hortaz, ezinbestekoa da nanomaterialen balizko toxikotasunaren ikerketa sakonagoa egitea, gizartean seguruak direla zabaldu ahal izateko.

\section{ESKER ONAK}

Eskerrak eman nahi dizkiogu Eusko Jaurlaritzari (GIC-IT-570-13 erreferientziadun Ikerketa Taldearen laguntzagatik) eta Ekonomia eta Lehiakortasun Espainiako Ministerioari MAT2016-78266-P proiektuagatik.

\section{BIBLIOGRAFIA}

[1] European Commission, http://ec.europa.eu/ (2017/12/19)

[2] Hitzaldia: «There's Plenty of Room at the Bottom» Caltech-en 1959ko abenduaren 29n Fisikako Elkarte Amerikarraren bileran, http://www.zyvex.com/ nanotech/feynman.html (2017/12/20).

[3] POLETTE, L.A., MEITZNER, G., YACAMAN, M.J. eta CHIANELLI, R.R. 2002. «Maya blue: application of XAS and HRTEM to materials science in art and archaeology». Microchemical Journal, 71, 167-174.

[4] MEULEBROECK, W., WOUTERS, H., NYS, K. eta THIENPONT, H. 2016. «Authenticity screening of stained glass windows using optical spectroscopy». Scientific Reports, 6, 37726.

[5] LEONHARDT, U. 2007. «Invisibility cup». Nature Photonics, 1, 207-208.

[6] CHENG, J.C., TIRSELL, K.G., TRIPP, G.R., LENT, E.M. eta LERCHE, R.A. 1978. «Streak camera measurement of subnanosecond plastic scintillator properties». Review of Scientific Instruments, 49, 650-653. 
[7] GÖPEL, W. 1995. «Controlled signal transduction across interfaces of «intelligent» molecular systems». Biosensors and Bioelectronics, 10, 35-59.

[8] DUNCAN, V.T. 2011. «Applications of nanotechnology in food packaging and food safety: Barrier materials, antimicrobials and sensors». Journal of Colloid and Interface Science, 363, 1-24.

[9] RASHIDI, L. eta KHOSRAVI-DARANI, K. 2011. «The Applications of Nanotechnology in Food Industry». Critical Reviews in Food Science and Nutrition, 51, 723-730.

[10] CHAUNDRHY, Q., CASTLE, L. eta WATKINS, R. 2010. Nanotechnologies in food. RSC Cambridge, UK.

[11] PARAK, W.J., NEL, A.E. eta WEISS, P.S. 2015. «Grand Challenges for Nanoscience and Nanotechnology». ACS Nano, 9, 6637-6640.

[12] SANTERAMO, F.G., CARLUCCI, D., DE DEVITIIS, B., SECCIA, A., STASI, A., VISCECCHIA, R. eta NARDONE, G. 2018. «Emerging trends in European food, diets and food industry». Food Research International, 104, 39-47.

[13] KING, T., OSMOND-McLEOD, M.J. eta DUFFY, L.L. 2018. «Nanotechnology in the food sector and potential applications for the poultry industry». Trends in Food Science \& Technology, 72, 62-73.

[14] HERNANDEZ-SANCHEZ, H. eta GUTIERREZ-LOPEZ, G.F. 2015. Food Nanoscience and Nanotechnology. Springer International Publishing, New York.

[15] ECHIEGU, E.A. 2017. Nanotechnology. Nanotechnology Applications in the Food Industry. Springer, Singapore

[16] EZHILARASI, P.N., KARTHIK, P., CHHANWAL, N. eta ANANDHARAMAKRISHNAN, C. 2013. «Nanoencapsulation Techniques for Food Bioactive Components: A Review». Food and Bioprocess Technology, 6, 628-647.

[17] UBBINK, J. eta KRUGER, J. 2006. «Physical approaches for the delivery of active ingredients in foods». Trends in Food Science \& Technology, 17, 244254.

[18] SINGH, T., SHUKLA, S., KUMAR, P., WAHLA, V., BAJPAI, V.K. eta RATHER, I. A. 2017. «Application of Nanotechnology in Food Science: Perception and Overview». Frontiers in Microbiology, 8, 01501.

[19] JOYE, I.J., DAVIDOV-PARDO, G. eta McCLEMENTS, D.J. 2014. «Nanotechnology for increased micronutrient bioavailability». Trends in Food Science \& Technology, 40, 168-182.

[20] HAMAD, A.F., HAN, J.H., KIM, B.C. eta RATHER, I.A. 2018. «The intertwine of nanotechnology with the food industry». Saudi Journal of Biological Sciences, 25, 27-30.

[21] ETXABIDE, A., URANGA, J., GUERRERO, P. eta DE LA CABA, K. 2018. «Manufaktura metodoen eta saretze erreakzioaren eragina gelatinazko materialen propietateetan» Ekaia, DOI: 10.1387/ekaia.19635.

[22] PEElmANA, N., RAGAERTA, P., MEUlEnAER, B., ADONS, D., PEETERS, D., CARDOND, L., IMPE, F.V. eta DEVLIEGHERE, F. 2013. 
«Application of bioplastics for food packaging». Trends in Food Science \& Technology, 32, 128-141.

[23] ARORA, A. eta PADUA, G.W. 2010. «Nanocomposites in Food Packaging». Journal of Food Science, 75, R43-R45.

[24] ANDRADE DEL OLMO, J. eta PEREZ ALVAREZ, L. 2018. «Elikagaien paketatze aktiborako polimeroen gainazalaren aldaketa» Ekaia, 33, 129-148.

[25] DE AZEREDO, H.M.C. 2009. «Nanocomposites for food packaging applications». Food Research International, 42, 1240-1253.

[26] AlEXANDre, B., LANGEVIN, D., MÉdÉRIC, P., AUBRY, T., COUDERC, H., NGUYEN, Q.T., SAITER, A. eta MARAIS, S. 2009. «Water barrier properties of polyamide 12 /montmorillonite nanocomposite membranes: Structure and volume fraction effects». Journal of Membrane Science, 328, 186-204.

[27] TAKEUCHI N. 2009. Nanociencia y nanotecnología: la construcción de un mundo mejor átomo por átomo. Fondo de Cultura Económica, Mexiko.

[28] SHARMA, A., GOYAL, A.K. eta RATH, G. 2018. «Recent advances in metal nanoparticles in cancer therapy». Journal of Drug Targeting, 26, 617632.

[29] KHATOON, U.T., RAO, G.V.S.N., MANTRAVADI, K.M. eta OZTEKIN, Y. 2018. «Strategies to synthesize various nanostructures of silver and their applications - a review». RSC Advances, 8, 19739-19753.

[30] KAMPMANN, Y., DE CLERCK, E., KOHN, S., PATCHALA, D.K., LANGEROCK, R. eta KREYENSCHMIDT, J. 2008. «Study on the antimicrobial effect of silver-containing inner liners in refrigerators». Journal of Applied Microbiology, 104, 1808-1814.

[31] HAJIPOUR, M.J., FROMM, K.M., ASHKARRAN, A.A., JIMENEZ DE ABERASTURI, D., RUIZ DE LARRAMENDI, I., ROJO, T., SERPOOSHAN, V., PARAK, W.J. eta MAHMOUDI, M. 2012. «Antibacterial properties of nanoparticles». Trends in Biotechnology, 32, 499-511.

[32] HANDFORD, C.E., DEAN, M., HENCHION, M., SPENCE, M., ELLIOT, C.T. eta CAMPBELL, K. 2014. «Implications of nanotechnology for the agri-food industry: Opportunities, benefits and risks». Trends in Food Science \& Nanotechnology, 40, 226-241.

[33] SHARMA, C., DHIMAN, R., ROKANA, N. eta PANWAR, H. 2017. «Nanotechnology: An Untapped Resource for Food Packaging». Frontiers in Microbiology, 8, 1735.

[34] BANERJEE, S., PILLAI, S.C., FALARAS, P., O'SHEA, K.E., BYRNE, J.A. eta DIONYSIOU, D.D. 2014. «New insights into the mechanisms of visible light photocatalysis». The Journal of Physical Chemistry Letters, 5, 2543-2554.

[35] Green Earth Nano Science Inc. http://www.greenearthnanoscience.com/ $(2018 / 2 / 20)$.

[36] CUSHEN, M., KERRY, J., MORRIS, M., CRUZ-ROMERO, M. eta CUMMINS, E. 2014. «Evaluation and Simulation of Silver and Copper Nanopar- 
ticle Migration from Polyethylene Nanocomposites to Food and an Associated Exposure Assessment». Journal of Agricultural and Food Chemistry, 62, 1403-1411.

[37] DAVARCIOGLU, B. 2017. Nanotechnology. Nanotechnology Applications in Food Packaging Industry. Springer, Singapore.

[38] MILLS, A. 2005. «Oxygen indicators and intelligent inks for packaging food». Chemical Society Reviews, 34, 1003-1011.

[39] DEL BIANCO, A., BALDINI, F., BACCI, M., KLIMANT, I. eta WOLFBEIS, O. 1993. "A new kind of oxygen-sensitive transducer based on an immobilized metallo-organic compound». Sensors and Actuators B Chemical, 11, 347-350.

[40] MILLS, A. eta WELLS, N. 2015. «Reductive photocatalysis and smart inks». Chemical Society Reviews, 44, 2849-2864.

[41] MILLS, A. eta HAZAFY. 2008. «A solvent-based intelligence ink for oxygen». Analyst, 133, 213-218.

[42] IMRAN, M., YOUSAF, A.B., ZHOU, X., LIANG, K., JIANG, Y.-F. eta XU, A.-W. 2016. «Oxygen-Deficient $\mathrm{TiO}_{2-x}$ /Methylene Blue Colloids: Highly Efficient Photoreversible Intelligent Ink». Langmuir, 32, 8980-8987.

[43] CHUAH, A.S.F., LEONG, A.D., CUMMINGS, C.L. eta HO, S.S. 2018. «Label it or ban it? Public perceptions of nano-food labels and propositions for banning nano-food applications». Journal of Nanoparticle Research, 20, 36 . 